\title{
How Do They Do It? - Understanding the Success of Marine Invasive Species
}

\author{
Jonas C. Geburzi and Morgan L. McCarthy
}

\section{Abstract}

From the depths of the oceans to the shallow estuaries and wetlands of our coasts, organisms of the marine environment are teeming with unique adaptations to cope with a multitude of varying environmental conditions. With millions of years and a vast volume of water to call their home, they have become quite adept at developing specialized and unique techniques for survival and - given increasing human mediated transport - biological invasions. A growing world human population and a global economy drives the transportation of goods across the oceans and with them invasive species via ballast water and attached to ship hulls. In any given 24-hour period, there are about 10,000 species being transported across different biogeographic regions. If any of them manage to take hold and establish a range in an exotic habitat, the implications for local ecosystems can be costly. This review on marine invasions highlights trends among successful non-indigenous species (NIS), from vectors of transport to ecological and physiological plasticity. Apart from summarizing patterns of successful invasions, it discusses the implications of how successfully established NIS impact the local environment, economy and human health. Finally, it looks to the future and discusses what questions need to be addressed and what models can tell us about what the outlook on future marine invasions is.

J. C. Geburzi $(\bowtie)$

Zoological Institute and Museum, Kiel University, Kiel, Germany

Alfred Wegener Institute, Helmholtz Centre for Polar and Marine Research, Wadden Sea Station, List/Sylt, Germany

e-mail: jonas.geburzi@zoolmuseum.uni-kiel.de

M. L. McCarthy

School of Biological Sciences, The University of Queensland,

St. Lucia, QLD, Australia

Marine Biology, Vrije Universiteit Brussel (VUB),

Brussels, Belgium

e-mail: m.1.mccarthy@uq.net.au

\section{Introduction}

The continuously rising numbers and extending ranges of non-indigenous species (NIS) are today widely seen as a major biological aspect of global change, affecting invaded ecosystems, economy and even human health (Vitousek et al. 1996; Ruiz et al. 2000; Simberloff et al. 2013). Marine species have been anthropogenically introduced into new habitats since humans travel overseas. However, only in the past 150 years, and especially the latter half of the $20^{\text {th }}$ century, technical advances and extreme increases in global marine trade led to the exponential increase of marine species introductions (Carlton and Geller 1993; Bax et al. 2003).

Of the hundreds of species that get introduced to habitats out of their native range, only a small fraction actually establishes permanently in their new environment. An even smaller fraction reaches high population densities and/or successfully disperses over wider ranges with adverse impacts on the recipient system - being consequently termed 'invasive species' (Sakai et al. 2001; Colautti and MacIsaac 2004). The growing field of invasion biology uses various approaches, e.g., ecology, physiology, evolution, and genetics, to investigate mechanisms and consequences of the establishment of NIS. Finding answers to the questions what makes certain species successful invaders and how invasion processes actually happen is a main focus of invasion biology. These often include aspects that predict impacts of invasive species on the invaded communities and may disclose starting points for possible management strategies (e.g., Bremner 2008; Williams and Grosholz 2008). Furthermore, the study of biological invasions offers model systems to better understand general biological processes such as species interactions, physiological and ecological adaptations, and evolutionary processes (Ruiz et al. 2000; Stachowicz et al. 2002; Facon et al. 2006). While marine systems globally are amongst the most heavily invaded ones, they have long been underrepresented in invasion biology studies compared to terrestrial and limnic systems. A main reason for this might 
be the vastness and open character of marine systems, which require higher (technical) efforts and make it generally more difficult to detect, investigate and manage marine invasions. However, this discrepancy is reduced by a quickly growing body of literature in recent years (Grosholz and Ruiz 1996; Ruiz et al. 2000; Chan and Briski 2017).

Even though it is difficult to identify universal factors and traits that lead to high invasion success due to its apparent dependency on the individual conditions of each invasion event (Sakai et al. 2001), some general patterns regularly occur in this context. These include for example common invasion pathways and vectors (Katsanevakis et al. 2013), as well as anthropogenic alterations or perturbations of recipient habitats (Bax et al. 2000; Briggs 2012; Mineur et al. 2012). Additional factors are high ecological and physiological plasticity of successful invaders (Hänfling et al. 2011; Parker et al. 2013; Tepolt and Somero 2014), and the general nature of interactions between native and non-native as well as among non-native species (Snyder and Evans 2006; Johnson et al. 2009; Briggs 2010). This review aims to give an introductory overview of important aspects of successful marine invasions, including human impacts, species' traits and interactions, and invasion genetics. The second part of this review copes with ecological and socio-economic consequences of marine invasions and their implications for policy and management, and closes with an outlook on future developments of the phenomenon under the perspectives of ongoing global (esp. climate) change. For clarification purposes, a glossary defining the most important terms can be found in Box 1.

\section{Box 1: Glossary \\ Cryptogenic species:}

Dispersal pathway:
(Crypt-Greek, kryptos, secret; -genic, New Latin, genic, origin) as a species that is not demonstrably native or introduced (Carlton 1996).

The combination of processes and opportunities resulting in the movement of propagules from one area to another, including aspects of the vectors involved, features of the origi-
Hybridization:

\section{Non-native/alien/exo-tic/ foreign/intro-duced/ non-indigenous:}

Vector: nal and recipient environments, and the nature and timing of what exactly is moved (Wilson et al. 2009).

The interbreeding of individuals of morphologically and presumably genetically distinct populations, regardless of the taxonomic status of such populations (Short 1969).

Native/indigenous/original: An organism occurring within its natural past or present range and dispersal potential (organisms whose dispersal is independent of human intervention) (Falk-Petersen et al. 2006, modified from IUCN 2000).

An organism occurring outside its natural past or present range and dispersal potential including any parts of the organism that might survive and subsequently reproduce (organisms whose dispersal is caused by human action) (Falk-Petersen et al. 2006, modified from IUCN 2000).

The physical means or agent by which a species is transported, such as ballast water, ships' hulls, boats, hiking boats, cars, vehicles, packing material, or soil in nursery stock (Carlton 2001). 


\section{Promoters of Successful Spread and Establishment}

\section{Vectors, Pathways and Altered Habitats - Human Impacts}

Anthropogenic activities are, by definition, major prerequisites for the occurrence of marine NIS, as only they allow species to reach regions beyond their natural range and dispersal limits. Besides obvious examples of direct species transportation, either intentional or unintentional, human impacts on marine habitats can also indirectly act as strong promoters of the spread and establishment of marine NIS.

Ship traffic is the most important vector of species' introductions (Fig. 1). Ships act as vectors in two ways. First, their hulls provide a habitat for fouling communities of sessile species, which are transported between ports and may eventually get removed or detached, or release offspring into a new environment (Ruiz et al. 1997; Gollasch 2002). If the fouling layer is thick enough, mobile species may survive transoceanic transport in sheltered cavities, as for example the Asian crab Hemigrapsus takanoi, which was first recorded in Europe in 1993 on a ship's hull (Gollasch 1999, then identified as $H$. penicillatus). Second, the exchange of huge amounts of ballast water holds the potential for all species with (at least temporal) planktonic or swimming lifestyle to be taken up in one and be released in another port. Since the 1880s, when seawater started to replace solid ballast, the number of marine NIS and the frequency of introductions has been constantly increasing (Carlton and Geller 1993; Ruiz et al. 1997; Ruiz and Smith 2005; Wolff 2005). The ongoing trend to ever more, bigger, and faster vessels fuels this trend by increasing ballast water volume and thus the number of transported organisms, as well as their survival probability. The importance of international ship traffic for the dispersal of marine NIS is also underlined by the fact that especially international ports and their surroundings have often turned into hot-spots for exotic species and that the dispersal routes of many species follow the main transoceanic shipping routes (Briggs 2012; Seebens et al. 2013). While the big container vessels and other large trading ships account to a large extent for primary species introductions across continents, regional traffic of smaller ships are important vectors for the secondary spread (range-expansion) of marine NIS. Recent studies showed that recreational boating is a particularly important driver of regional dispersal of nonnative species (e.g. Clarke Murray et al. 2011; Hänfling et al. 2011).

Aquaculture is another important vector for marine NIS, which also accounts for a rising number of introductions parallel to the global growth of this economy during the last decades (Naylor et al. 2001). Organisms with a planktonic larval stage are especially prone to 'spill over' from their culture areas into the surrounding habitats. This introduction pathway led, for example, to the invasion of the Pacific oyster Magallana gigas along the southeastern coast of the European North Sea. The species was initially believed to not be able to reproduce in the cold climate of the North Sea, but a series of warm summers following the introduction of M. gigas promoted their dispersal. The case of $M$. gigas highlights how a combination of human actions, environmental change and species' traits can lead to a successful invasion (Diederich et al. 2005; Smaal et al. 2009). Aquaculture is not only a vector for the cultured target spe-

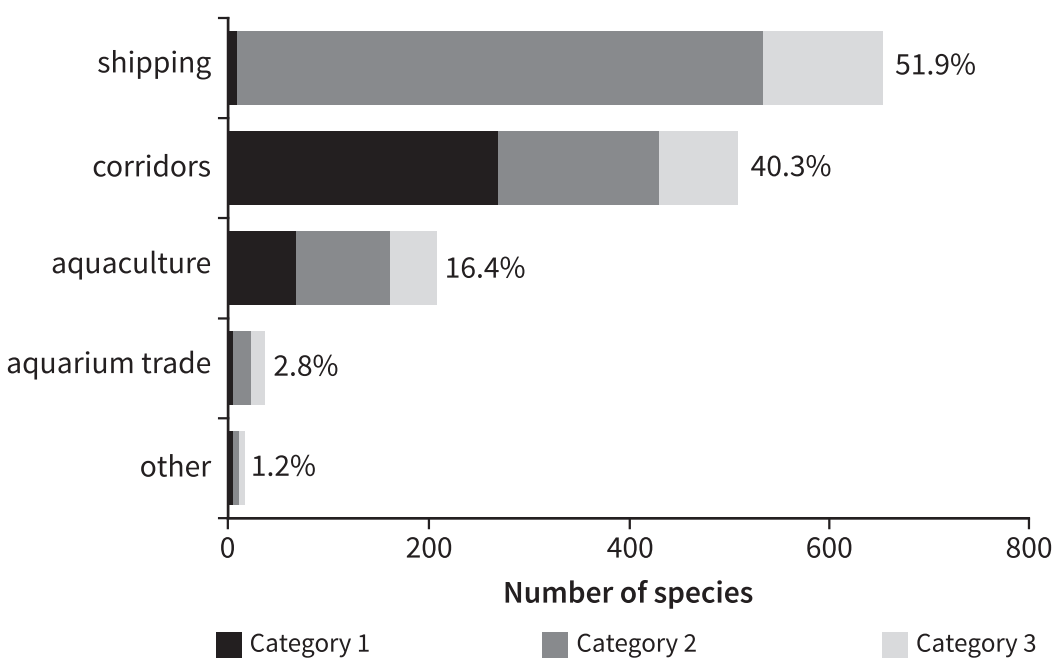

Fig. 1 Number of marine NIS in Europe, known or likely to be introduced by each of the main vectors. Percentages add to more than $100 \%$ as 147 out of the 1,264 species are linked to more than one vector. Categories refer to the certainty by which a species can be linked to a vector: (1) there is direct evidence of a vector; (2) a most likely vector can be inferred; (3) one or more possible vectors can be inferred. Redrawn and modified from Katsanevakis et al. (2013) with permission from Elsevier. 
cies, but often also unintentionally introduces organisms, which are associated with them if they are not vigorously cleaned before transportation. Worldwide, the introductions of more than 40 marine species can be directly linked to the translocation of bivalves used in aquaculture (Padilla et al. 2011), and in total 206 NIS have been linked to this vector in Europe alone (Katsanevakis et al. 2013; Fig. 1). Particularly invasive ecosystem-engineers like reef-building oysters (esp. M. gigas and Crassostrea virginica) promote the establishment of NIS they brought along by providing favorable habitats, which eventually further enhances community shifts in the invaded systems (e.g., Ruiz et al. 2000; Markert et al. 2010; Padilla et al. 2011). Another important taxon in this context are macroalgae, which are regularly introduced as 'blind passengers' with aquaculture organisms. They can likewise change existing or form new habitats, thus affecting both native and other alien species (e.g., Jones and Thornber 2010; Salvaterra et al. 2013; Thomsen et al. 2016).

Floating (plastic) litter is a vector recently gaining attention. While the marine litter problem is mostly discussed under the aspect of pollution and the hazardous effects of microplastic accumulation, larger pieces of litter are also a possible habitat for fouling organisms, which might then be transported over large distances by oceanic currents. Recent studies found a variety of species from different taxonomic groups (including bryozoans, barnacles and mollusks) settling on macroplastic, with a considerable proportion of marine NIS among them (Barnes and Milner 2005; Gregory 2009; Gil and Pfaller 2016). While driftwood and other debris may already historically have played a role in the cosmopolitan distribution of species like Teredo navalis (Bivalvia, Myoida) or Lepas anatifera (Crustacea, Pedunculata), the recent extreme increase in amounts of marine litter may lead to a future increase in numbers on marine NIS dispersed by this vector (Gregory 2009).

Trade of ornamental and aquarium-kept organisms has been widely neglected by scientists and policy makers as an introduction pathway, although it bears a high potential for species invasions (Padilla and Williams 2004). Introductions of aquarium organisms to natural environments may occur accidentally, when organisms escape during transport or, for example, from public aquaria with in-/outflow from/to natural water bodies, or intentionally, when hobbyists or traders release single individuals or discard the contents of whole aquaria into the wild. Fish and macroalgae are the taxa with the highest numbers of species (potentially) introduced by aquarium trade. Zenetos et al. (2016) list 19 introduced fish species with a potential link to this vector in the Mediterranean Sea alone, and Vranken et al. (2018) identified at least 23 seaweed species commonly found in aquaria across Europe, which have the potential to thrive European natural waters, with the highly invasive Caulerpa taxifolia as the most striking example (compare also Padilla and Williams 2004;
Fig. 1). Besides the usually ornamental target species, aquarium trade may also account for unintentional introductions of associated species, especially epibionts on seaweeds and live rock used for aquarium decoration, such as macro- and microalgae, (hemi)sessile cnidarians, crustaceans, polychaetes or mollusks (Padilla and Williams 2004). Aquarium trade is a strongly growing economy, and commercial and private online retailers make exotic species easily available worldwide via the internet, rendering this vector extremely difficult to control and regulate (Padilla and Williams 2004; Mazza et al. 2015; Vranken et al. 2018). Today, the Mediterranean and southern European Atlantic are the regions within Europe which are most affected by this introduction pathway, due to the (sub)tropical origin of most of the traded species. In the light of ongoing ocean warming, also more temperate regions might get invaded by these species in the future (Vranken et al. 2018). Thus, the number of marine invasions promoted by aquarium trade are very likely to increase in the future.

Although not thought of as a 'classical' vector, canals are a major introduction pathway for marine NIS. The best known example is the Suez Canal, connecting the Mediterranean Sea to the Red Sea and Indian Ocean, which accounts for the vast majority of species invasions to the Mediterranean by migration through the canal (Lessepsian migration) (Galil 2009). The Baltic Sea, as another example, was invaded by numerous ponto-caspian species since it is connected to the Black Sea by a system of canals and rivers (Leppäkoski et al. 2002; Katsanevakis et al. 2013). Additionally, the Kiel Canal provides a shortcut route between the southwestern Baltic and the southeastern North Sea. It likely served as an invasion pathway for numerous species native or invasive to the Atlantic, like the crabs Rhithropanopeus harrisii and H. takanoi (Fowler et al. 2013; Geburzi et al. 2015). An interesting case in this context is the shrimp Palaemon elegans, of which an Atlantic type invaded the Baltic Sea from the west, and a Mediterranean/Black Sea-type invaded from the southeast (Reuschel et al. 2010). Besides opening routes for the active migration or natural (e.g., larval) dispersal processes, canals also increase the probability for successful ship-mediated introductions, as they shorten transportation times, thus increasing survival probabilities, e.g., for organisms in ballast water tanks.

Human activities not only provide vectors and pathways for species' introductions, but they also impact the environment in ways that can promote the establishment success of marine NIS, in particular by changing natural habitats. The 'invasibility' of a community or habitat, i.e., its receptivity towards invasive species, can be strongly influenced by human activities. Apart from the propagule pressure of invaders, it largely depends on the availability of suitable niches and resources. Anthropogenic habitat changes (addition or depletion of different niches) and disturbances leading to a reduction in native diversity (increasing resource 
Fig. 2 Factors that have been shown to affect invasions of non-native species into marine communities. Propagules of NIS may be supplied by various vectors and propagule pressure is influenced by reproductive traits of these species. When they are able to survive under the environmental conditions of the new habitat ("Abiotic filter'), their ability to invade the community is influenced by several, potentially interacting factors that affect resource availability, as well as the NIS' biological traits (modified after Olyarnik et al. 2009 , with permission from Springer). See text for details and examples.

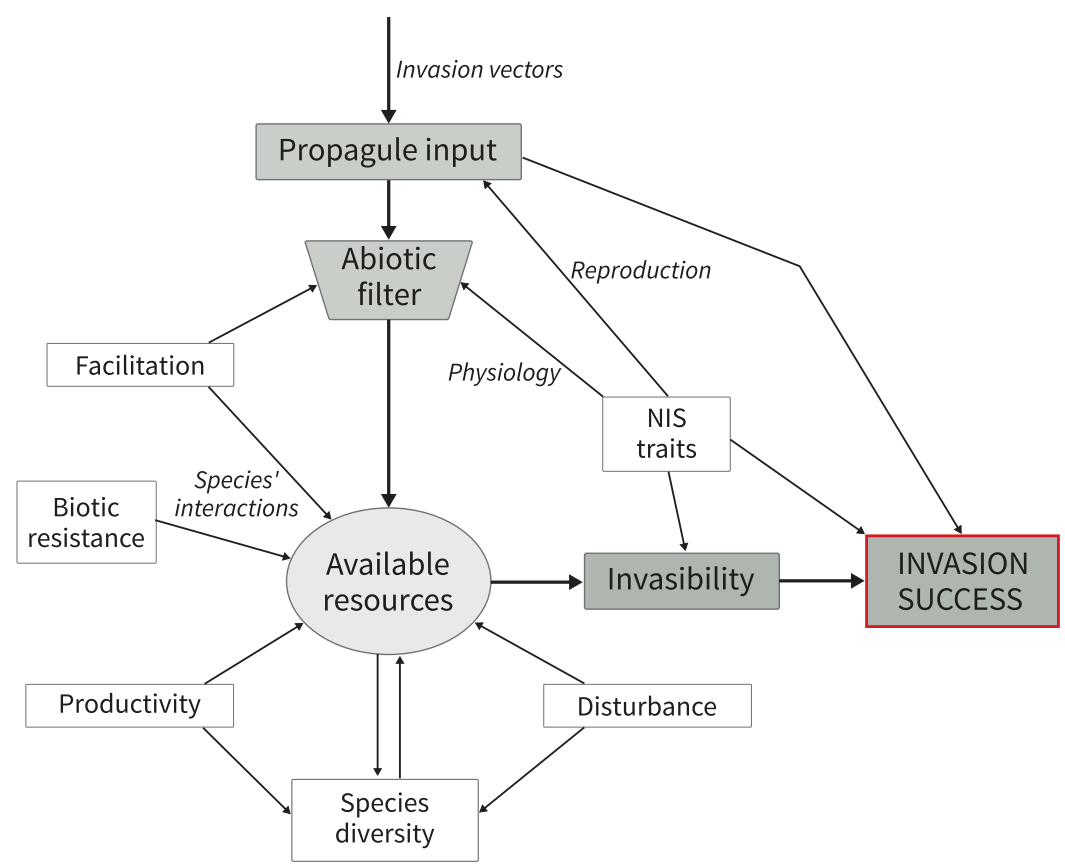

availability for invaders) are thus important determinants of invasibility (Colautti et al. 2006; Fridley et al. 2007; Fig. 2). The construction of harbors and coastal defense structures such as groins or seawalls on sedimentary coasts or in estuaries, for example, adds artificial rocky habitats to naturally soft-bottomed environments. Such new habitats are often rapidly colonized by non-native species as native species are less adapted to their conditions (Mineur et al. 2012). They may also serve as 'stepping stones' for the dispersal of rocky-shore species (Landschoff et al. 2013), a function which is also currently investigated with regard to the increasing number of offshore wind farms (De Mesel et al. 2015). Water pollution and eutrophication are discussed as additional anthropogenic impacts which lead to disturbances of marine ecosystems and communities, making them more receptive to invasions (Reise et al. 2006; Briggs 2007). Several experimental studies revealed in fact a higher tolerance of NIS towards anthropogenic abiotic stress (i.e., water pollution) compared to related native taxa in marine communities (e.g., Piola and Johnston 2008; Crooks et al. 2010; Lenz et al. 2011). However, observational studies often show that invasions occur likewise in disturbed and pristine habitats, and that NIS are affected by disturbances as well (Klein et al. 2005; Boudouresque and Verlaque 2012, and references therein), indicating a more complex relationship between disturbance, native diversity, and invasibility. Clark and Johnston (2011) showed that the relationship between disturbance and invader success changes over time, being highly positive for initial invasions (due to increased resource availability by the reduction in native diversity), but turning to a negative relationship for later stages of establishment. The high prevalence of marine invasions in disturbed habi- tats might rather be due to the fact that these are often at the same time heavily affected by introduction vectors such as shipping and aquaculture (compare Colautti et al. 2006; Boudouresque and Verlaque 2012).

\section{Life History, Ecology and Physiology - Species' Traits}

Of the high numbers of transported and introduced species, only a small proportion successfully establishes and becomes invasive. Several ecological and life-history traits regularly occur in marine invasive species from different taxa and can, therefore, be associated with their success. Overall, the following traits and examples show that plasticity, for example in life-history strategies, behavior, and physiology, is a key feature of successful invaders.

Many of these traits are associated with reproduction, as in the end reproductive success is the one factor determining whether a species successfully establishes and spreads (Fig. 2). Invaders are often characterized by an $r$-selected breeding strategy (early maturity, short generation time, high fecundity, rapid growth rates) or the ability to switch between $r$ - and $K$-selected strategies (reviewed in Sakai et al. 2001), enabling them to develop a high propagule pressure even from small founder populations. Likewise, the ability of females to produce several broods per season when environmental conditions allow for it has been often observed (Hines 1986; Anderson and Epifanio 2010; van den Brink et al. 2013). For crabs in particular, Zeng et al. (2014) discuss the ability to switch between, or combine, two strategies of resource allocation for reproduction as a potential promoter 
of invasiveness. The authors suggest that successful invaders might be able to use both, internal repositories as well as external energy sources, during reproduction, allowing for higher fecundity or extended breeding periods (Zeng et al. 2014). In some cases, seasonality also seems to have facilitated the establishment of NIS. Temporally shifted breeding periods are for example believed to reduce competition between early juveniles of native crabs and the invasive European shore crab Carcinus maenas in Australia (Garside et al. 2015).

Having a planktonic larval stage is a common feature of many marine taxa, but it provides particular benefits for establishing NIS by increasing their dispersal abilities. This trait mostly affects the secondary regional spread after the initial introduction of a species. Some marine NIS possess a significantly longer duration of larval development compared to native species of the same taxonomic group, which is regarded as a mean of further enhancing the dispersal potential (Roman and Palumbi 2004; Viard et al. 2006; Delaney et al. 2012; Katsanevakis et al. 2013). The choice of recruitment sites by the last larval stages is often positively influenced by chemical signals released by conspecifics (gregarious settlement), but for some successful invaders cues from suitable habitat act as strong as recruitment enhancer as conspecific cues. This mechanism has for example been shown for the crab Hemigrapsus sanguineus and is believed to enhance the species' ability to colonize new habitats (O'Connor 2007; Anderson and Epifanio 2009).

Resource utilization and food preference is another set of traits, where successful invaders often show high levels of plasticity. Omnivory (in animals) and the ability to quickly adapt to a changed food supply is often observed (e.g., Blasi and O'Connor 2016) and allows NIS to avoid food competition with native species of the same guild. On the other hand, newly arrived species can also cause dietary shifts in native species, being both, beneficial for themselves but detrimental for the native competitor (Griffen et al. 2011).

A species physiology is an important component in determining its ability to take hold in a new habitat (Fig. 2). In order for an invader to take hold and remain, it must pass biotic and abiotic conditions, known as the "ecological filter" of the environment (Crowl et al. 2008). Abiotic factors are the first part of the filter that NIS must endure. They must be able to survive physiological adjustments and abiotic stressors such as temperature, desiccation, and disturbance (Olyarnik et al. 2009). Granted a species is able to endure the abiotic factors, they must also be able to maintain performance and fitness through competition (Levine et al. 2004) and predation (deRivera et al. 2005) with other species in the environment. Failing to survive through this filter can prevent establishment or range expansion (Kelley 2014).

Temperature and salinity are two factors highly regarded in limiting an organism's ability to expand its range as a NIS, as is the case in Mytilus studies (Pickens 1965; Helm and Trueman 1967; Coleman and Trueman 1971; Stickle and Sabourin 1979; Nicholson 2002; Braby and Somero 2006a). Mytilus trossulus is native to the North Pacific, however, has been replaced along the California coastline from the Mexican border to Monterey Bay after the introduction of Mytilus galloprovincialis, a Mediterranean native, to Southern California via shipping in the 1900s (McDonald and Koehn 1988; Geller 1999). A habitat mosaic exists in San Francisco and Monterey Bay, which are both characterized by varying abiotic environmental conditions (Braby and Somero 2006b). While the invasive mussel (Mytilus galloprovincialis) is genetically inclined to high temperature thermal tolerance, Mytilus trossulus is well adapted to areas achieving a critical salinity level, making the matrix of habitats in Monterey and San Francisco Bay a mixed mosaic, where otherwise Mytilus galloprovincialis had displaced it along the southern coast given its thermal tolerance acclimation advantage (Braby and Somero 2006a).

In some cases, NIS are able to sustain populations in new ranges despite not being physiologically capable of reproduction in the surrounding environment. This is a leading hypothesis for the Chinese Mitten Crab Eriocheir sinensis in the Baltic Sea. Though other theories exist, evidence suggests that the Elbe River estuary is a donor area for E. sinensis, and that individuals are migrating to the Baltic via the Kiel Canal, traveling distances up to $1,500 \mathrm{~km}$ (Ojaveer et al. 2007). Under unfavourable combinations of temperature and salinity, it has been shown that additional larval stages may occur in E. sinensis (Ojaveer et al. 2007), which is a phenomenon unique among brachyuran crabs (Montú et al. 1996). Other crab species have also shown regional adaptations to physiological parameters. Populations of the European shore crab C. maenas in the Baltic Sea (salinity 15) have shown a higher capacity for hyper-regulation than populations of $C$. maenas in the North Sea (salinity 30) (Theede 1969).

\section{Competition, Facilitation and Parasitism - Species' Interactions}

Wherever NIS are introduced, they develop interactions with both native and other non-native species in their new habitat. At the same time, detrimental interactions with species of their native range, such as predators, parasites or pathogens, may fall away in the invaded range ("enemy-releasehypothesis', see e.g., Jeschke et al. 2012; Papacostas et al. 2017). Either way, shifts in the interaction regimes of NIS during the invasion process are probably among the most important factors determining the long-term potential for a successful establishment after initial introduction.

Many invasive species are known as strong competitors, having negative effects on native species occupying the same 
niche, which, in turn, facilitates their own or their offspring's establishment. Common mechanisms are superiority in the competition for food and shelter or for optimal settlement space in the case of sessile animals and plants, respectively (Ruiz et al. 1999; Jensen et al. 2002; Levin et al. 2002; van den Brink et al. 2012; Katsanevakis et al. 2013). Several studies also reported direct predation pressure by invaders on native species within the same guild (Ruiz et al. 1999, and references therein). Some authors (Briggs 2010) relate the strong competitiveness of many NIS to a regularly observed biogeographical pattern of marine invasions: They often originate from regions with high biodiversity (e.g., the western and central Indo-Pacific and the NW-Pacific for NIS in Europe, see Tsiamis et al. 2018) and are, therefore, well adapted to strong competition. This makes them superior over native species of their recipient regions, which are often characterized by lower biodiversity. This pattern is also incorporated in the 'enemy-release-hypothesis' (Bax et al. 2001; Brockerhoff and McLay 2011), and assumed to significantly contribute to the observation that successful invaders often 'perform better' (grow bigger, reproduce more) in their invaded compared to their native ranges (Parker et al. 2013).

The success of marine NIS may also be enhanced by positive interactions which benefit the invader. They have been described to occur among species invading the same region, where the establishment of a first species (often an ecosystemengineer, see section "Vectors, Pathways and Altered Habitats - Human Impacts") facilitates subsequent invasions of further species (Fridley et al. 2007; Altieri and Irving 2017). The initial invader might either directly provide beneficial effects for subsequent invaders (e.g., habitat or food) or exert detrimental effects for native competitors of subsequent invaders (e.g., predation, pathogens, structural habitat changes, Fig. 2). Such cascading effects have led to the assumption that increasingly invaded systems become more susceptible to further introductions, cumulating in 'invasional meltdown' scenarios (Simberloff and Von Holle 1999; Grosholz 2005). Empirical evidence for 'invasional meltdown' is however scarce (Simberloff 2006; Briggs 2012). At the same time, an increasing number of studies report both negative interactions between NIS (Lohrer and Whitlatch 2002; Griffen et al. 2008; Griffen 2016) and positive effects of NIS on native species (Rodriguez 2006, and references therein). In summary, these studies underline the complexity of species interactions in the context of NIS establishment, making predictions on general interaction patterns and longterm invasion success extremely difficult.

Parasitism is another type of species' interaction with the potential to strongly affect invasion success. Just like being released from enemies, a release from parasites often occurs during the translocation process of many species, resulting in a much lower parasite load of introduced compared to native populations (Snyder and Evans 2006; McDermott 2011; Fowler et al. 2013). Direct positive effects of reduced parasite load include, for example, increased survival and fecundity (especially, when released from sterilizing parasites). Even more important are the indirect effects by the reduced need to invest in parasite defense, allowing organisms to reallocate those resources to traits like growth or reproduction (Goedknegt et al. 2016). Reduced investment in parasite defense, however, results in higher susceptibility to parasite infections, which may in turn negatively impact establishment success (Keogh et al. 2016). Introduced non-native parasites, on the other hand, can reach extreme invasion success when they are able to infect native species which are closely related to their original host, but have only weak defensive traits due to the lack of coevolution (examples in Ruiz et al. 1999; Feis et al. 2016). This could theoretically even promote the invasion success of the original host, which may gain competitive advantages over its native relative by being better adapted to infections.

\section{Selection, Multiple Introductions and Hybridization - Invasion Genetics}

Species introductions have the potential to trigger rapid evolutionary changes and adaptation processes acting on the genetic level. Invasion genetics, therefore, play an important role in determining long-term success of species introductions and their evolutionary consequences for the respective species (Holland 2000; Geller et al. 2010). Furthermore, invasion genetics is a tool to determine the origin of invasive species and potential pathways of introduction. The Veined rapa whelk (Rapana venosa), for example, is genetically highly diverse in native Chinese populations (Yang et al. 2008), but genetically monomorphic in all introduced populations in Europe and the Americas. This implies that all introduced populations originate from one single introduction, which has been localized in the Black Sea (Chandler et al. 2008). Similarly, all invasive populations of the seaweed Caulerpa taxifolia in the Mediterranean, Australia and North America could be traced back genetically to a strain that was released or escaped from a European aquarium (Wiedenmann et al. 2001; Padilla and Williams 2004).

Usually, introduction and colonization processes of species into new habitats are associated with a considerable reduction of genetic diversity by strong genetic drift or bottleneck effects. One would, therefore, expect to regularly observe negative effects of genetic depletion in newly establishing populations, especially a reduced ability to adapt to changing environmental conditions. This seems, however, often not to be the case (a terrestrial example in Tsutsui et al. 2000; Hänfling 2007). Possible reasons are for example cosegregation of fixed loci or changes in frequencies of rare 
(recessive) alleles caused by the reduction of population size, leading to an actual increase in additive genetic diversity (Hänfling 2007, and references therein; Facon et al. 2008). If, by chance events, advantageous genotypes develop under these conditions, they can rapidly become fixed in a small founder population due to the strong selective forces. Multiple introductions of the same species can further mitigate possibly negative effects of small founder populations. They will be often not recognized as long as no genetic studies are performed ('cryptic invasions'), but are likely to occur in many introduced species. If repeated introductions originate from different source populations, this leads to an admixture of genotypes, holding the potential to strongly increase the adaptive abilities of the species by novel combination of alleles (Hänfling 2007; Herborg et al. 2007; Chan and Briski 2017). This is believed to considerably contribute to the invasiveness of global invaders like the European shore crab Carcinus maenas (Geller et al. 1997; Roman 2006).

Hybridization between native species and NIS regularly occurs in animals with external fertilization like mollusks and fish, and especially in plants. From the invaders perspective, it increases the chances to successfully establish despite small founder population sizes either by introgression of native alleles which enhance adaptive evolution, or by the development of new hybrid lineages combining beneficial traits from both parental lineages (Sakai et al. 2001; Hänfling 2007). The latter can occasionally lead to hybrid superiority and eventually result in the displacement of native species by newly evolved hybrids. This has been for example observed for cordgrass, Spartina sp., in Great Britain and North America, where hybrids between native and invasive species disperse more successfully than their parent species (Huxel 1999; Williams and Grosholz 2008, and references therein).

\section{Why Does It Matter?}

\section{Ecological Impacts}

The evidence is overwhelming that NIS invasions are a significant stressor to marine communities and has been observed in invasions by plants, fish, crabs, snails, clams, mussels, bryozoans, and nudibranchs (Ruiz et al. 1999). Furthermore, anthropogenic derived disturbances and the introduction of new species are skewing food webs towards a loss of higher trophic groups and a gain in lower order consumers (Byrnes et al. 2007). On the other hand, the invasion of marine NIS may increase local biodiversity, as marine invaders often appear to accommodate besides native species rather than replacing them (Briggs 2007; an example in Reise et al. 2017). As a higher biodiversity stabilizes communities, invaders may also have overall positive effects, especially in otherwise disturbed habitats. This can also include the resistance against further invasions (Stachowicz et al. 2002; Marraffini and Geller 2015). Species most likely to have wide-reaching ecosystem impacts are those that alter the biotic and abiotic factors of the environment, namely ecosystem engineers (Vitousek et al. 1996).

An ecosystem engineer is an organism that alters the availability of resources to other species. Jones et al. (1994) described ecosystem engineers as falling into two categories, autogenic and allogenic. Autogenic engineers change the environment through their own physical structure. Corals for example, provide habitats for many reef dwelling species. Allogenic engineers alter the environment by transforming living or non-living materials between physical states, as is the case for sea urchins which alter the environment by eating the kelp that would otherwise be providing a habitat for organisms as autogenic engineers (Jones et al. 1994). Broadly speaking, NIS as ecosystem engineers can provide both positive and negative impacts on their environments. As a prominent example, Pacific oysters (Magallana gigas) have been introduced globally for aquaculture purposes and have in some cases established wild oyster beds among its introduced ranges (Lejart and Hily 2011). The impact of Pacific oysters has varied from displacement of Sabellaria reefs, a species of conservation importance, to increases in sessile invertebrate diversity via secondary settlement on oyster shells (Olyarnik et al. 2009; Herbert et al. 2016).

Apart from the introduction of ecosystem engineers themselves, the introduction of pathogens can indirectly cause a significant alteration to the physical environment by infecting ecosystem engineers. The introduced protistan pathogens Haplosporidium nelsoni and Perkinsus marinus were partly responsible for the decline of the Virginia oyster (Crassostrea virginica) (Crooks 2002), a historically important ecosystem engineer in the Chesapeake Bay. The Chesapeake Bay has seen a decrease in over $90 \%$ of its oyster population in the last century and the pathogen introduction has been recorded as a dominant factor of mortality. Additionally, results of the pathogen introduction have limited the physical structure of oysters as a habitat and as a filter feeder, altering the benthic and planktonic food webs (Ruiz et al. 1999).

Positive ecological impacts of NIS also occur outside the group of ecosystem engineers. For example, the mitten crab E. sinensis is able to transfer native and non-native invertebrates to new habitats (Ojaveer et al. 2007). The large carapace acts as a substrate for flora and fauna (e.g., algae and barnacles) to inhabit. Furthermore, the 'hairy' patches on the crabs' claws could also provide a habitat for nematodes, bivalves, crustaceans, oligocheates, and gastropods (Normant et al. 2007). Other ecological advantages include new food sources for fish, novel habitats, and increased biofiltration. In a recent meta-analysis, Katsanevakis et al. (2014) found that among the assessed NIS, $35 \%$ had been reported to have a positive impact on other species. 


\section{The Economy and Human Health}

Social and economic impacts are linked to invasive species altering fisheries, aquaculture, tourism, and marine infrastructure activities. Human health is also impacted, when the consequence of these alterations results in lost revenue and, potentially, a direct decrease in human health (Bax et al. 2001).

The economy drives the exchange of goods across the globe via shipping routes and trade and with it come new NIS. In some instances, NIS have negative economic impacts by altering ecosystems and reducing the stocks of exportable fish and shellfish through competition and disease. Few studies focus on the economic impacts of aquatic species alone and even fewer separate out marine from freshwater species impacts. In a recent case study, Ünal and Bodur (2017) investigated the negative impacts of Silver-cheeked toadfish Lagocephalus scleratus on small-scale fisheries in the eastern Mediterranean Sea. Marine invasions pose an additional challenge because of the widely dispersing planktonic larvae of some marine species (Thresher and Kuris 2004).

The European green crab Carcinus maenas, ranked in the IUCN list of the 'world's worst invasive alien species' (Lowe et al. 2004) has had quite an economic impact in North America since emerging from its native European range over 200 years ago (Carlton and Cohen 2003). The estimated annual losses to shellfisheries on the East Coast of the United States due to predation by $C$. maenas alone range from $\$ 14.7$ to $\$ 18.7$ million a year and sum up to $\$ 805.9$ million during the period from 1975 to 2005 (Abt Associates Inc. 2008). In addition to loss of profit from shellfish sales, green crabs are also responsible for the loss of eelgrass in restoration projects through bioturbation activities such as foraging and burrowing (Davis et al. 1998). The associated costs from these activities range from $\$ 60,150$ to $\$ 77,433$ as an estimate for the year 2006 (Abt Associates Inc. 2008). Apart from the costs associated with direct shellfish predation and eelgrass restoration projects, there are also projected costs for handling further losses from the NIS. Expenditures for a proposed monitoring and control program to the US Environmental Protection Agency would cost $\$ 285,000$ per year (Abt Associates Inc. 2008). The European shore crab is just one NIS, in one country and calculations are based on only the known impacts. Carlton (1999) and others demonstrated through the European shore crab that the economic cost of a single NIS can be quite significant, highlighting the need for effective control and management implementation. Keller et al. (2011) highlight the possibility that there may be economic benefits in some cases. The release of the Red king crab Paralithodes camtschaticus into the Barents Sea and subsequent expansion into the Norwegian coast provided an income of over 9 million EUR for fisherman (Galil et al. 2009). Other edible NIS used in fisheries or aquaculture include the fish Planiliza haematocheila, Saurida lessepsianus, Siganus luridus, S. rivulatus, the molluscs Ensis directus, Mercenaria mercenaria and Aerococcus viridans var. homari (Katsanevakis et al. 2014).

While known impacts of NIS can be calculated to the dollar, other factors may not have a monetary label, especially those concerning human health. Lafferty and Kuris (1996) describe the risk that the Chinese mitten crab in California presents as a second intermediate host for the Oriental lung fluke Paragonimus westermani, which can cause paralysis in humans. If the mitten crab becomes widely abundant, it may serve as a suitable host for the native North American lung flukes and increase the potential for infection in humans (Lafferty and Kuris 1996).

\section{Management and Policy}

As Thresher and Kuris (2004) summarize, there are management efforts in outbreaks across the globe, from the marine alga Caulerpa taxifolia in California, the Mediterranean Sea and Australia (Meinesz et al. 2001; Cheshire et al. 2002; Williams and Grosholz 2002) to the Asian whelk Rapana venosa in the Chesapeake Bay (Mann and Harding 2000) and the Asian mussel Perna viridis in Cairns, Australia (Thresher and Kuris 2004). These examples illustrate that marine invasions are truly a global challenge. In meeting this challenge, the study highlights four key differences between management in marine and terrestrial invasion approaches. The first is that the ocean is perceived as an open system and that, due to global patterns of circulation, pelagic larvae and large-scale migrations, local eradication efforts are insignificant. The open nature of the ocean establishes a defeatist attitude among public managers. Another challenge to marine invasions is who should bear the burden of cost. The benefits of management actions can be widespread and, therefore, which parties should be involved in paying for them can become convoluted. Furthermore, the public perceives the ocean and open coastline to be pristine, allowing invasions to go largely unnoticed by the public. Thus, public awareness typically does not arise until the later stages of the invasion process (expansion and persistence), while at the same time containment and other management efforts grow increasingly difficult (Fig. 3). Finally, scientific literature on the biology of most marine taxa is limited, making decisions and predicting outcomes of management practices difficult (Thresher and Kuris 2004). Despite these additional challenges in managing marine invasions, there have been approaches developed which have produced mixed results.

Lovell et al. (2006) highlights some of the policies developed to limit the spread of NIS. Two main approaches to international policy have been to focus on shipping vectors as a means of distribution, and by limiting the amount 


\section{Stages of invasion}

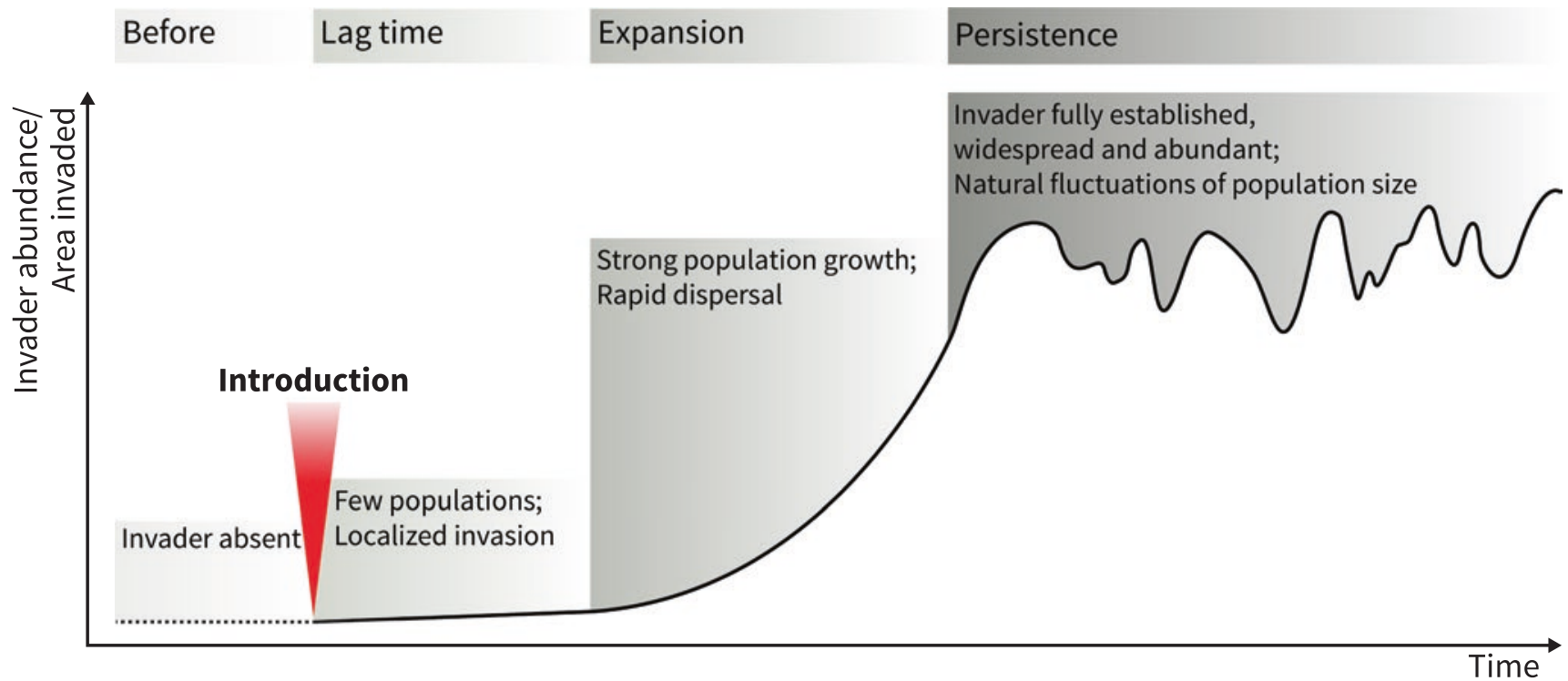

\section{Stages of management}

Prevention
$\begin{aligned} & \text { Control of } \\ & \text { vectors and } \\ & \text { pathways }\end{aligned}$

Eradication
$\begin{aligned} & \text { Measures for } \\ & \text { eradication might } \\ & \text { be successful }\end{aligned}$

Containment

Prevention of further spread;

Public awareness

typically begins

\section{Long-term management}

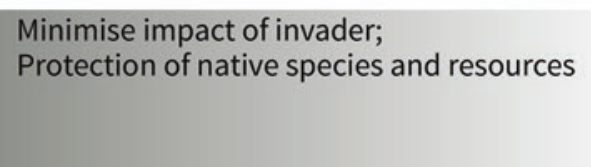

Fig. 3 Theoretical invasion curve (black line), stages of the invasion process and according stages of invasive species management (after Boudouresque et al. 2005; State of Victoria 2010; Gothland et al. 2014). Preventive measures before the introduction are the most effective and least disturbing to the environment. Once the expansion stage is reached, management is limited to containment of the invader and minimization of its impacts. of imports via quarantine bans or tariffs (Lovell et al. 2006). Despite regulations, trade among the North Atlantic Free Trade Area (NAFTA) countries spreads invasive species that were introduced as a result of trade with countries outside of NAFTA (Perrault et al. 2003). It is in this manner that NIS can be introduced and widely distributed among trade partners who themselves adhere to stringent treaty regulations.

A mere handful of marine focused management recommendations have been suggested and are summarized by Secord (2003). Recommendations are centered around prevention and control. The least disturbing to the environment is the prevention of invasions in the first place (Fig. 3). This may be manifested through public education and outreach programs, ballast water exchange and treatment options, and regulation in the aquaculture industry and aquarium trade (Secord 2003). Second is the eradication of small invasive populations, while they are still susceptible to localized chemical or mechanical control methods (Fig. 3). This may take form through shading algal species, chlorine treatment of marinas, or the physical smashing of individual snail hosts of an invasive parasite (Bax 1999; Culver and Kuris 2000; Dalton 2000). Invasions can further be augmented through biocontrol using native species. The advantage of this method is that it introduces no further NIS, however, the implications for affected community dynamics may be put at risk. The most risky method to local ecosystem dynamics is through the introduction of other NIS to eat, parasitize, infect or compete with the invader (Secord 2003). Finally, public education, supporting research, and monitoring all help to inform, when management actions should be implemented or when new invaders have arrived.

Returning to the example of $C$. maenas, one considered bioinvasion control for this species was the introduction of the castrating barnacle Sacculina carcini. After infiltrating the crab body, the parasite castrates both male and females, effectively prohibiting its hosts from reproducing (Lafferty and Kuris 1996). The danger in this form of bioinvasion control is how it would impact native as well as commercially valuable crabs or shrimp (Secord 2003). 


\section{Future Implications in Light of Climate Change}

Future studies should consider marine invasions in light of changing climate conditions. As sea level rises, how will it influence the expansion of NIS ranges? If bodies of water are connected by larger channels and increased water flow, how will this impact the spread of future invasions? Will prone to acclimatizing NIS thrive, when new areas of land sink beneath the rising oceans?

Educating the public on marine NIS is an important step towards keeping invasions in check. The ocean is large and looking out at it from on land, it can seem undisturbed and peaceful. Beneath the surface, however, NIS are thriving under rocks and floating through the water column as microscopic plankton. Using molecular genetic techniques, we can first study the past and use it to understand how established NIS came to be. Through further monitoring, we can keep invasions in check and observe, whether new invasions are underway. Finally, by carefully predicting climatic conditions of the future, we can hypothesize about the course of future marine invasions and begin to plan future management campaigns in light of global climate change.

Climate change is expected to impact aquatic invasions by warming water temperatures, altering water flow patterns, and increasing storm events (Poff et al. 2002). Aquatic systems that are naturally saline will likely increase in salinity, though, whether this will necessarily allow marine species to invade inland waters is still largely unknown (Rahel and Olden 2008). Climate change will also result in physiological changes, which will become apparent at the population level and as seen by shifts in abundance, timing of annually recurring events and distribution and dispersion of organisms (Doney et al. 2012). For example, invasive ectotherms have a greater ability to acclimate their thermal tolerance and can achieve a higher upper thermal tolerance threshold than native ectotherms (Kelley 2014). As Occhipinti-Ambrogi (2007) highlights, the range expansions of populations of NIS has already been observed to be coupled with increasing water temperatures. The Mediterranean Sea has witnessed the establishment of alien microalgae species, an increase that is largely attributed to increased water temperatures (Gómez and Claustre 2003). Other microalgae, whose spread is also thought to be linked to increasing water temperatures, has impacted human health. The NIS Ostreopsis cf. ovata, which bloomed in the Ligurian sea, caused respiratory illness in tourists exposed to it (Brescianini et al. 2006; Durando et al. 2007; Vila et al. 2016).

One of the most comprehensive models for predicting the fate of marine invasions found that overall there would be a high species turnover rate attributed to invasions and extinc- tions by the mid- $21^{\text {st }}$ century. In considering the distributional ranges of 1,066 marine fish and invertebrates for 2050 in a bioclimate envelope model, Cheung et al. (2009) found that patterns of species invasion as well as turnover (accounting for invading and locally extinct species) were predicted in high latitude regions of the Arctic and Southern Ocean and that, combined with global extinctions, invasions and extinctions will amount to a turnover of $60 \%$ of the present biodiversity. The potential disruptions in ecosystem services in the future based on this model remain yet to be known. With a growing world population and in light of a changing global climate, studies are needed to better understand how marine invasions will further impact our environment and economy, and how managers can better prepare for future invasions.

Acknowledgements The authors thank A. Zenetos and an anonymous reviewer for their comments, which greatly improved the manuscript.

\section{Appendix}

This article is related to the YOUMARES 8 conference session no. 11: "How Do They Do It? - Understanding the Success of Marine Invasive Species". The original Call for Abstracts and the abstracts of the presentations within this session can be found in the appendix "Conference sessions and Abstracts", chapter "7 How Do They Do It? Understanding the Success of Marine Invasive Species", of this book.

\section{References}

Abt Associates Inc (2008) Ecological and economic impacts and invasion management strategies for the European Green Crab. Cambridge, MA

Altieri AH, Irving AD (2017) Species coexistence and the superior ability of an invasive species to exploit a facilitation cascade habitat. Peer J 5:e2848. https://doi.org/10.7717/peerj.2848

Anderson JA, Epifanio CE (2009) Induction of metamorphosis in the Asian shore crab Hemigrapsus sanguineus: characterization of the cue associated with biofilm from adult habitat. J Exp Mar Bio Ecol 382:34-39. https://doi.org/10.1016/j.jembe.2009.10.006

Anderson JA, Epifanio CE (2010) Mating and sperm storage of the Asian shore crab Hemigrapsus sanguineus. J Shellfish Res 29:497501. https://doi.org/10.2983/035.029.0228

Barnes DKA, Milner P (2005) Drifting plastic and its consequences for sessile organism dispersal in the Atlantic Ocean. Mar Biol 146:815825. https://doi.org/10.1007/s00227-004-1474-8

Bax NJ (1999) Eradicating a dreissenid from Australia. Dreissena! $10: 1-5$

Bax NJ, Hayes K, Marshall A et al (2000) Man-made marinas as sheltered islands for alien marine organisms: establishment and eradication of an alien invasive marine species. In: Veitch CR, Clout MN 
(eds) Turning the tide: the eradication of invasive species. IUCN SSC Invasive Specialist Group, Gland, pp 26-39

Bax NJ, Carlton JT, Mathews-Amos A et al (2001) The control of biological invasions in the world's oceans. Conserv Biol 15:12341246. https://doi.org/10.1046/j.1523-1739.2001.99487.x

Bax NJ, Williamson A, Aguero M et al (2003) Marine invasive alien species: a threat to global biodiversity. Mar Policy 27:313-323

Blasi JC, O'Connor NJ (2016) Amphipods as potential prey of the Asian shore crab Hemigrapsus sanguineus: Laboratory and field experiments. J Exp Mar Bio Ecol 474:18-22. https://doi.org/10.1016/j. jembe.2015.09.011

Boudouresque C-F, Verlaque M (2012) An overview of species introduction and invasion processes in marine and coastal lagoon habitats. Cah Biol Mar 53:309-317

Boudouresque C-F, Ruitton S, Verlaque M (2005) Large-scale disturbances, regime shift and recovery in littoral systems subject to biological invasions. In: Velikova V, Chipev N (eds) UNESCO-ROSTE/ BAS workshop on regime shifts. Varna, pp 85-101

Braby CE, Somero GN (2006a) Following the heart: temperature and salinity effects on heart rate in native and invasive species of blue mussels (genus Mytilus). J Exp Biol 209:2554-2566. https://doi. org/10.1242/jeb.02259

Braby CE, Somero GN (2006b) Ecological gradients and relative abundance of native (Mytilus trossulus) and invasive (Mytilus galloprovincialis) blue mussels in the California hybrid zone. Mar Biol 148:1249-1262. https://doi.org/10.1007/s00227-005-0177-0

Bremner J (2008) Species' traits and ecological functioning in marine conservation and management. J Exp Mar Bio Ecol 366:37-47. https://doi.org/10.1016/j.jembe.2008.07.007

Brescianini C, Grillo C, Melchiorre N et al (2006) Ostreopsis ovata algal blooms affecting human health in Genova, Italy, 2005 and 2006. Euro Surveillance2 11:3040

Briggs JC (2007) Marine biogeography and ecology: invasions and introductions. J Biogeogr 34:193-198. https://doi. org/10.1111/j.1365-2699.2006.01632.x

Briggs JC (2010) Marine biology: the role of accommodation in shaping marine biodiversity. Mar Biol 157:2117-2126. https://doi. org/10.1007/s00227-010-1490-9

Briggs JC (2012) Marine species invasions in estuaries and harbors. Mar Ecol Prog Ser 449:297-302. https://doi.org/10.3354/meps09553

Brockerhoff AM, McLay CL (2011) Human-Mediated Spread of Alien Crabs. In: Galil BS, Clark PF, Carlton JT (eds) In the wrong place - alien marine crustaceans: distribution, biology and impacts. Springer, Dordrecht, pp 27-106

Byrnes JE, Reynolds PL, Stachowicz JJ (2007) Invasions and extinctions reshape coastal marine food webs. PLoS ONE 2:e295. https:// doi.org/10.1371/journal.pone.0000295

Carlton JT (1996) Biological Invasions and Cryptogenic Species. Ecology 77:1653-1655

Carlton JT (1999) The scale and ecological consequences of biological invasions in the World's oceans. In: Sandlund OT, Schei PJ, Viken $\AA$ (eds) Invasive species and biodiversity management. Kluwer Academic Publishers, Dordrecht, pp 195-212

Carlton JT (2001) Introduced species in US coastal waters: environmental impacts and management priorities. Pew Oceans Commission, Arlington, Virginia

Carlton JT, Cohen AN (2003) Episodic global dispersal in shallow water marine organisms: the case history of the European shore crabs Carcinus maenas and C. aestuarii. J Biogeogr 30:1809-1820. https://doi.org/10.1111/j.1365-2699.2003.00962.x

Carlton JT, Geller JB (1993) Ecological roulette: the global transport of nonindigenous marine organisms. Science 261:78-82. https://doi. org/10.1126/science.261.5117.78

Chan FT, Briski E (2017) An overview of recent research in marine biological invasions. Mar Biol 164:121. https://doi.org/10.1007/ s00227-017-3155-4
Chandler EA, McDowell JR, Graves JE (2008) Genetically monomorphic invasive populations of the rapa whelk, Rapana venosa. Mol Ecol 17:4079-4091. https://doi.org/10.1111/j.1365-294X.2008.03897.x

Cheshire A, Westphalen G, Boxall V et al (2002) Caulerpa taxifolia in West Lakes and the Port River: distribution and eradication options. Adelaide, Australia

Cheung WWL, Lam VWY, Sarmiento JL et al (2009) Projecting global marine biodiversity impacts under climate change scenarios. Fish Fish 10:235-251. https://doi.org/10.1111/j.1467-2979. 2008.00315.x

Clark GF, Johnston EL (2011) Temporal change in the diversity - invasibility relationship in the presence of a disturbance regime. Ecol Lett 14:52-57. https://doi.org/10.1111/j.1461-0248.2010.01550.x

Clarke Murray C, Pakhomov EA, Therriault TW (2011) Recreational boating: A large unregulated vector transporting marine invasive species. Divers Distrib 17:1161-1172. https://doi. org/10.1111/j.1472-4642.2011.00798.x

Colautti RI, MacIsaac HJ (2004) A neutral terminology to define "invasive" species. Divers Distrib 10:135-141. https://doi. org/10.1111/j.1366-9516.2004.00061.x

Colautti RI, Grigorovich IA, MacIsaac HJ (2006) Propagule pressure: a null model for biological invasions. Biol Invasions 8:1023-1037. https://doi.org/10.1007/s10530-005-3735-y

Coleman N, Trueman ER (1971) The effect of aerial exposure on the activity of the mussels Mytilus edulis L. and Modiolus modiolus (L.). J Exp Mar Bio Ecol 7:295-304. https://doi. org/10.1016/0022-0981(71)90011-6

Crooks JA (2002) Characterizing ecosystem-level consequences of biological invasions: the role of ecosystem engineers. Oikos 97:153-166

Crooks JA, Chang AL, Ruiz GM (2010) Aquatic pollution increases the relative success of invasive species. Biol Invasions 13:165-176. https://doi.org/10.1007/s10530-010-9799-3

Crowl TA, Crist TO, Parmenter RR et al (2008) The spread of invasive species and infectious disease as drivers of ecosystem change. Front Ecol Environ 6:238-246. https://doi.org/10.1890/070151

Culver CS, Kuris AM (2000) The apparent eradication of a locally established introduced marine pest. Biol Invasions 2:245-253. https://doi.org/10.1023/A:1010082407254

Dalton R (2000) Researchers criticize response to killer algae. Nature 406:447-447

Davis RC, Short FT, Burdick DM (1998) Quantifying the effects of green crab damage to eelgrass transplants. Restor Ecol 6:297-302. https://doi.org/10.1046/j.1526-100X.1998.00634.x

De Mesel I, Kerckhof F, Norro A et al (2015) Succession and seasonal dynamics of the epifauna community on offshore wind farm foundations and their role as stepping stones for non-indigenous species. Hydrobiologia 756:37-50. https://doi.org/10.1007/ s10750-014-2157-1

Delaney DG, Edwards PK, Leung B (2012) Predicting regional spread of non-native species using oceanographic models: validation and identification of gaps. Mar Biol 159:269-282. https://doi. org/10.1007/s00227-011-1805-5

deRivera CE, Ruiz GM, Hines AH et al (2005) Biotic resistance to invasion: native predator limits abundance and distribution of an introduced crab. Ecology 86:3364-3376. https://doi. org/10.1890/05-0479

Diederich S, Nehls G, van Beusekom JE et al (2005) Introduced Pacific oysters (Crassostrea gigas) in the northern Wadden Sea: Invasion accelerated by warm summers? Helgol Mar Res 59:97-106. https:// doi.org/10.1007/s10152-004-0195-1

Doney SC, Ruckelshaus M, Emmett Duffy J et al (2012) Climate change impacts on marine ecosystems. Ann Rev Mar Sci 4:11-37. https://doi.org/10.1146/annurev-marine-041911-111611

Durando P, Ansaldi F, Oreste P et al (2007) Ostreopsis ovata and human health: epidemiological and clinical features of respiratory syn- 
drome outbreaks from a two-year syndromic surveillance, 2005-06, in north-west Italy. Euro Surveill 12:3212. https://doi.org/10.2807/ esw.12.23.03212-en

Facon B, Genton BJ, Shykoff J et al (2006) A general eco-evolutionary framework for understanding bioinvasions. Trends Ecol Evol 21:130-135. https://doi.org/10.1016/j.tree.2005.10.012

Facon B, Pointier JP, Jarne P et al (2008) High genetic variance in lifehistory strategies within invasive populations by way of multiple introductions. Curr Biol 18:363-367. https://doi.org/10.1016/j. cub.2008.01.063

Falk-Petersen J, Bøhn T, Sandlund OT (2006) On numerous concepts in invasion biology. Biol Invasions 8:1409-1424. https://doi. org/10.1007/s10530-005-0710-6

Feis ME, Goedknegt MA, Thieltges DW et al (2016) Biological invasions and host-parasite coevolution: different coevolutionary trajectories along separate parasite invasion fronts. Zoology 119:366-374. https://doi.org/10.1016/j.zool.2016.05.012

Fowler AE, Forsström T, von Numers M et al (2013) The North American mud crab Rhithropanopeus harrisii (Gould, 1841) in newly colonized Northern Baltic Sea: distribution and ecology. Aquat Invasions 8:89-96. https://doi.org/10.3391/ai.2013.8.1.10

Fridley JD, Stachowitz TJ, Naeem S et al (2007) The invasion paradox: reconciling pattern and process in species invasions. Ecology 88:3-17

Galil BS (2009) Taking stock: inventory of alien species in the Mediterranean sea. Biol Invasions 11:359-372. https://doi. org/10.1007/s10530-008-9253-y

Galil BS, Gollasch S, Minchin D et al (2009) Alien marine biota of Europe. In: Hulme PE, Nentwig W, Pyšek P et al (eds) Handbook of Alien Species in Europe. Springer, Dordrecht, pp 93-104

Garside CJ, Glasby TM, Stone LJ et al (2015) The timing of Carcinus maenas recruitment to a south-east Australian estuary differs to that of native crabs. Hydrobiologia 762:41-53. https://doi.org/10.1007/ s10750-015-2332-z

Geburzi JC, Graumann G, Köhnk S et al (2015) First record of the Asian crab Hemigrapsus takanoi Asakura \& Watanabe, 2005 (Decapoda, Brachyura, Varunidae) in the Baltic Sea. BioInvasions Rec 4:103107. https://doi.org/10.3391/bir.2015.4.2.06

Geller JB (1999) Decline of a native mussel masked by sibling species invasion. Conserv Biol 13:661-664. https://doi. org/10.1046/j.1523-1739.1999.97470.x

Geller JB, Walton ED, Grosholz ED et al (1997) Cryptic invasions of the crab Carcinus detected by molecular phylogeography. Mol Ecol 6:901-906. https://doi.org/10.1046/j.1365-294X.1997.00256.x

Geller JB, Darling JA, Carlton JT (2010) Genetic perspectives on marine biological invasions. Ann Rev Mar Sci 2:367-393. https:// doi.org/10.1146/annurev.marine.010908.163745

Gil MA, Pfaller JB (2016) Oceanic barnacles act as foundation species on plastic debris: implications for marine dispersal. Sci Rep 6:19987. https://doi.org/10.1038/srep19987

Goedknegt MA, Feis ME, Wegner KM et al (2016) Parasites and marine invasions: ecological and evolutionary perspectives. J Sea Res 113:11-27. https://doi.org/10.1016/j.seares.2015.12.003

Gollasch S (1999) The Asian decapod Hemigrapsus penicillatus (De Haan, 1835) (Grapsidae, Decapoda) introduced in european waters: status quo and future perspective. Helgoländer Meeresun 52:359_ 366. https://doi.org/10.1007/BF02908909

Gollasch S (2002) The importance of Ship Hull Fouling as a vector of species introductions into the North Sea. Biofouling 18:105-121

Gómez F, Claustre H (2003) The genus Asterodinium (Dinophyceae) as a possible biological indicator of warming in the western Mediterranean Sea. J Mar Biol Assoc UK 83:173-174. https://doi. org/10.1017/S0025315403006945h

Gothland M, Dauvin J-C, Denis L et al (2014) Biological traits explain the distribution and colonisation ability of the invasive shore crab Hemigrapsus takanoi. Estuar Coast Shelf Sci 142:41-49. https:// doi.org/10.1016/j.ecss.2014.03.012
Gregory MR (2009) Environmental implications of plastic debris in marine settings - entanglement, ingestion, smothering, hangerson, hitch-hiking and alien invasions. Philos Trans R Soc Lond B 364:2013-2025. https://doi.org/10.1098/rstb.2008.0265

Griffen BD (2016) Scaling the consequences of interactions between invaders from the individual to the population level. Ecol Evol 6:1769-1777. https://doi.org/10.1002/ece3.2008

Griffen BD, Guy T, Buck JC (2008) Inhibition between invasives: a newly introduced predator moderates the impacts of a previously established invasive predator. J Anim Ecol 77:32-40. https://doi. org/10.1111/j.1365-2656.2007.01304.x

Griffen BD, Altman I, Hurley J et al (2011) Reduced fecundity by one invader in the presence of another: a potential mechanism leading to species replacement. J Exp Mar Bio Ecol 406:6-13. https://doi. org/10.1016/j.jembe.2011.06.005

Grosholz ED (2005) Recent biological invasion may hasten invasional meltdown by accelerating historical introductions. Proc Natl Acad Sci USA 102:1088-1091. https://doi.org/10.1073/ pnas.0308547102

Grosholz ED, Ruiz GM (1996) Predicting the impact of introduced marine species: lessons from the multiple invasions of the european green crab Carcinus maenas. Biol Conserv 78:59-66

Hänfling B (2007) Understanding the establishment success of nonindigenous fishes: lessons from population genetics. J Fish Biol 71:115-135. https://doi.org/10.1111/j.1095-8649.2007.01474.x

Hänfling B, Edwards F, Gherardi F (2011) Invasive alien Crustacea: dispersal, establishment, impact and control. BioControl 56:573595. https://doi.org/10.1007/s10526-011-9380-8

Helm MM, Trueman ER (1967) The effect of exposure on the heart rate of the mussel, Mytilus edulis L. Comp Biochem Physiol 21:171177. https://doi.org/10.1016/0010-406X(67)90126-0

Herbert RJH, Humphreys J, Davies CJ et al (2016) Ecological impacts of non-native Pacific oysters (Crassostrea gigas) and management measures for protected areas in Europe. Biodivers Conserv 25:2835-2865. https://doi.org/10.1007/s10531-016-1209-4

Herborg L-M, Weetman D, van Oosterhout C et al (2007) Genetic population structure and contemporary dispersal patterns of a recent European invader, the Chinese mitten crab, Eriocheir sinensis. Mol Ecol 16:231-242. https://doi. org/10.1111/j.1365-294X.2006.03133.x

Hines AH (1986) Larval patterns in the life histories of Brachyuran crabs (Crustacea, Decapoda, Brachyura). Bull Mar Sci 39:444-466

Holland BS (2000) Genetics of marine bioinvasions. Hydrobiologia 420:63-71. https://doi.org/10.1023/A:1003929519809

Huxel GR (1999) Rapid displacement of native species by invasive species: effects of hybridization. Biol Conserv 89:143-152. https://doi. org/10.1016/S0006-3207(98)00153-0

IUCN (2000) IUCN guidelines for the prevention of biodiversity loss caused by alien invasive species. IUCN, Gland

Jensen GC, McDonald PS, Armstrong DA (2002) East meets west: competitive interactions between green crab Carcinus maenas, and native and introduced shore crab Hemigrapsus spp. Mar Ecol Prog Ser 225:251-262. https://doi.org/10.3354/meps225251

Jeschke JM, Gómez Aparicio L, Haider S et al (2012) Support for major hypotheses in invasion biology is uneven and declining. NeoBiota 14:1-20. https://doi.org/10.3897/neobiota.14.3435

Johnson PTJ, Olden JD, Solomon CT, Vander Zanden MJ (2009) Interactions among invaders: Community and ecosystem effects of multiple invasive species in an experimental aquatic system. Oecologia 159:161-170. https://doi.org/10.1007/ s00442-008-1176-x

Jones E, Thornber CS (2010) Effects of habitat-modifying invasive macroalgae on epiphytic algal communities. Mar Ecol Prog Ser 400:87-100. https://doi.org/10.3354/meps08391

Jones CG, Lawton JH, Shachak M (1994) Organisms as ecosystem engineers. Oikos 69:373-386 
Katsanevakis S, Zenetos A, Belchior C et al (2013) Invading European Seas: assessing pathways of introduction of marine aliens. Ocean Coast Manag 76:64-74. https://doi.org/10.1016/j. ocecoaman.2013.02.024

Katsanevakis S, Wallentinus I, Zenetos A et al (2014) Impacts of invasive alien marine species on ecosystem services and biodiversity: a pan-European review. Aquat Invasions 9:391-423. https://doi. org/10.3391/ai.2014.9.4.01

Keller RP, Geist J, Jeschke JM et al (2011) Invasive species in Europe: ecology, status, and policy. Environ Sci Eur 23:23. https://doi. org/10.1186/2190-4715-23-23

Kelley AL (2014) The role thermal physiology plays in species invasion. Conserv Physiol 2:1-14. https://doi.org/10.1093/conphys/ cou045

Keogh CL, Miura O, Nishimura T et al (2016) The double edge to parasite escape: invasive host is less infected but more infectable. Ecology 38:42-49. https://doi.org/10.1002/ecy.1953

Klein J, Ruitton S, Verlaque M et al (2005) Species introductions, diversity and disturbances in marine macrophyte assemblages of the northwestern Mediterranean Sea. Mar Ecol Prog Ser 290:79-88. https://doi.org/10.3354/meps290079

Lafferty KD, Kuris AM (1996) Biological control of marine pests. Ecology 77:1989-2000

Landschoff J, Lackschewitz D, Kesy K et al (2013) Globalization pressure and habitat change: Pacific rocky shore crabs invade armored shorelines in the Atlantic Wadden Sea. Aquat Invasions 8:77-87. https://doi.org/10.3391/ai.2013.8.1.09

Lejart M, Hily C (2011) Differential response of benthic macrofauna to the formation of novel oyster reefs (Crassostrea gigas, Thunberg) on soft and rocky substrate in the intertidal of the Bay of Brest, France. J Sea Res 65:84-93

Lenz M, da Gama BAP, Gerner NV et al (2011) Non-native marine invertebrates are more tolerant towards environmental stress than taxonomically related native species: results from a globally replicated study. Environ Res 111:943-952. https://doi.org/10.1016/j. envres.2011.05.001

Leppäkoski E, Gollasch S, Gruszka P et al (2002) The Baltic - a sea of invaders. Can J Fish Aquat Sci 59:1175-1188. https://doi. org/10.1139/f02-089

Levin PS, Coyer JA, Petrik R et al (2002) Community-wide effects of nonindigenous species on temperate rocky reefs. Ecology 83:3182-3193

Levine JM, Adler PB, Yelenik SG (2004) A meta-analysis of biotic resistance to exotic plant invasions. Ecol Lett 7:975-989. https:// doi.org/10.1111/j.1461-0248.2004.00657.x

Lohrer AM, Whitlatch RB (2002) Interactions among aliens: apparent replacement of one exotic species by another. Ecology 83:719-732

Lovell SJ, Stone SF, Fernandez L (2006) The economic impacts of aquatic invasive species: a review of the literature. Agric Resour Econ Rev 35:195-208. https://doi.org/10.1017/S1068280500010157

Lowe S, Browne M, Boudjelas S et al (2004) 100 of the world's worst invasive species: a selection from the global invasive species database. Invasive Species Specialist Group, Auckland

Mann R, Harding JM (2000) Invasion of the North American Atlantic coast by a large predatory Asian mollusc. Biol Invasions 2:7-22

Markert A, Wehrmann A, Kröncke I (2010) Recently established Crassostrea-reefs versus native Mytilus-beds: differences in ecosystem engineering affects the macrofaunal communities (Wadden Sea of Lower Saxony, southern German Bight). Biol Invasions 12:1532. https://doi.org/10.1007/s10530-009-9425-4

Marraffini ML, Geller JB (2015) Species richness and interacting factors control invasibility of a marine community. Proc R Soc B 282:20150439. https://doi.org/10.1098/rspb.2015.0439
Mazza G, Aquiloni L, Inghilesi A et al (2015) Aliens just a click away: the online aquarium trade in Italy. Manag Biol Invasions 6:253-261. https://doi.org/10.3391/mbi.2015.6.3.04

McDermott JJ (2011) Parasites of shore crabs in the genus Hemigrapsus (Decapoda: Brachyura: Varunidae) and their status in crabs geographically displaced: a review. J Nat Hist 45:2419-2441. https:// doi.org/10.1080/00222933.2011.596636

McDonald JH, Koehn RK (1988) The mussels Mytilus galloprovincialis and M. trossulus on the Pacific coast of North America. Mar Biol 99:111-118. https://doi.org/10.1007/BF00644984

Meinesz A, Belsher T, Thibaut T et al (2001) The introduced green alga Caulerpa taxifolia continues to spread in the Mediterranean. Biol Invasions 3:201-210

Mineur F, Cook EJ, Minchin D et al (2012) Changing coasts: marine aliens and artificial structures. Oceanogr Mar Biol An Annu Rev 50:189-234

Montú M, Anger K, de Bakker C (1996) Larval development of the Chinese mitten crab Eriocheir sinensis H. Milne-Edwards (Decapoda: Grapsidae) reared in the laboratory. Helgoländer Meeresun 50:223-252

Naylor RL, Williams SL, Strong DR (2001) Aquaculture - a gateway for exotic species. Science 294:1655-1656

Nicholson S (2002) Ecophysiological aspects of cardiac activity in the subtropical mussel Perna viridis (L.) (Bivalvia: Mytilidae). J Exp Mar Bio Ecol 267:207-222. https://doi.org/10.1016/ S0022-0981(01)00362-8

Normant M, Korthals J, Szaniawska A (2007) Epibiota associated with setae on Chinese mitten crab claws (Eriocheir sinensis H. MilneEdwards, 1853): a first record. Oceanologia 49:137-143

O'Connor NJ (2007) Stimulation of molting in megalopae of the Asian shore crab Hemigrapsus sanguineus: physical and chemical cues. Mar Ecol Prog Ser 352:1-8. https://doi.org/10.3354/meps07315

Occhipinti-Ambrogi A (2007) Global change and marine communities: alien species and climate change. Mar Pollut Bull 55:342-352. https://doi.org/10.1016/j.marpolbul.2006.11.014

Ojaveer H, Gollasch S, Jaanus A et al (2007) Chinese mitten crab Eriocheir sinensis in the Baltic Sea - a supply-side invader? Biol Invasions 9:409-418. https://doi.org/10.1007/s10530-006-9047-z

Olyarnik SV, Bracken MES, Byrnes JE et al (2009) Ecological factors affecting community invasibility. In: Rilov G, Crooks JA (eds) Biological invasions in marine ecosystems. Springer, Berlin, pp 215-238

Padilla DK, Williams SL (2004) Beyond ballast water: aquarium and ornamental trades as sources of invasive species in aquatic ecosystems. Front Ecol Environ 2:131-138. https://doi. org/10.1890/1540-9295(2004)002[0131:BBWAAO]2.0.CO;2

Padilla DK, Mccann MJ, Shumway SE (2011) Marine invaders and bivalve a quaculture: sources, impacts, and consequences. In: Shumway SE (ed) Shellfish aquaculture and the environment. Wiley, Chichester, pp 395-424

Papacostas KJ, Rielly-Carroll EW, Georgian SE et al (2017) Biological mechanisms of marine invasions. Mar Ecol Prog Ser 565:251-268. https://doi.org/10.3354/meps12001

Parker JD, Torchin ME, Hufbauer RA et al (2013) Do invasive species perform better in their new ranges? Ecology 94:985-994

Perrault A, Bennett M, Burgiel S et al (2003) Invasive species, agriculture and trade: case studies from the NAFTA context. In: Second North American symposium on assessing the environmental effects of trade, Mexico City, p 55

Pickens PE (1965) Heart rate of mussels as a function of latitude, intertidal height, and acclimation temperature. Physiol Zool 38:390-405. https://doi.org/10.1086/physzool.38.4.30152416 
Piola RF, Johnston EL (2008) Pollution reduces native diversity and increases invader dominance in marine hardsubstrate communities. Divers Distrib 14:329-342. https://doi. org/10.1111/j.1472-4642.2007.00430.x

Poff NL, Brinson MM, Day JW (2002) Aquatic ecosystems \& global climate change. Pew Center on Global Climate Change, Arlington

Rahel FJ, Olden JD (2008) Assessing the effects of climate change on aquatic invasive species. Conserv Biol 22:521-533. https://doi. org/10.1111/j.1523-1739.2008.00950.x

Reise K, Olenin S, Thieltges DW (2006) Are aliens threatening European aquatic coastal ecosystems? Helgol Mar Res 60:77-83. https://doi.org/10.1007/s10152-006-0024-9

Reise K, Buschbaum C, Büttger H et al (2017) Invading oysters and native mussels: from hostile takeover to compatible bedfellows. Ecosphere. https://doi.org/10.1002/ecs2.1949

Reuschel S, Cuesta JA, Schubart CD (2010) Marine biogeographic boundaries and human introduction along the European coast revealed by phylogeography of the prawn Palaemon elegans. Mol Phylogenet Evol 55:765-775. https://doi.org/10.1016/j. ympev.2010.03.021

Rodriguez LF (2006) Can invasive species facilitate native species? Evidence of how, when, and why these impacts occur. Biol Invasions 8:927-939. https://doi.org/10.1007/s10530-005-5103-3

Roman J (2006) Diluting the founder effect: cryptic invasions expand a marine invader's range. Proc R Soc B 273:2453-2459. https://doi. org/10.1098/rspb.2006.3597

Roman J, Palumbi SR (2004) A global invader at home: population structure of the green crab, Carcinus maenas, in Europe. Mol Ecol 13:2891-2898. https://doi.org/10.1111/j.1365-294X.2004.02255.x

Ruiz GM, Smith G (2005) Biological study of container vessels at the port of Oakland. Final report. Submitted to the Port of Oakland, $155 \mathrm{pp}$

Ruiz GM, Carlton JT, Grosholz ED et al (1997) Global invasions of marine and estuarine habitats by non-indigenous species: mechanisms, extent, and consequences. Am Zool 37:621-632. https://doi. org/10.1093/icb/37.6.621

Ruiz GM, Fofonoff PW, Hines AH et al (1999) Non-indigenous species as stressors in estuarine and marine communities: assessing invasion impacts and interactions. Limnol Oceanogr 44:950-972. https://doi.org/10.4319/lo.1999.44.3_part_2.0950

Ruiz GM, Fofonoff PW, Carlton JT et al (2000) Invasion of coastal marine communities in North America: apparent patterns, processes, and biases. Annu Rev Ecol Syst 31:481-531. https://doi. org/10.2307/annurev.ecolsys.37.091305.30000016

Sakai AK, Allendorf FW, Holt JS et al (2001) The population biology of invasive species. Annu Rev Ecol Syst 32:305-332. https://doi. org/10.1146/annurev.ecolsys.32.081501.114037

Salvaterra T, Green DS, Crowe TP et al (2013) Impacts of the invasive alga Sargassum muticum on ecosystem functioning and food web structure. Biol Invasions 15:2563-2576. https://doi.org/10.1007/ s10530-013-0473-4

Secord D (2003) Biological control of marine invasive species: cautionary tales and land-based lessons. Biol Invasions 5:117-131. https:// doi.org/10.1023/A:1024054909052

Seebens H, Gastner MT, Blasius B (2013) The risk of marine bioinvasion caused by global shipping. Ecol Lett 16:782-790. https://doi. org/10.1111/ele.12111

Short LL (1969) Aspects of avian hybridization. The Auk 86:84-105

Simberloff D (2006) Invasional meltdown 6 years later: important phenomenon, unfortunate metaphor, or both? Ecol Lett 9:912-919. https://doi.org/10.1111/j.1461-0248.2006.00939.x

Simberloff D, Von Holle B (1999) Positive interactions of nonindigenous species: invasional meltdown? Biol Invasions 1:21-32
Simberloff D, Martin JL, Genovesi P et al (2013) Impacts of biological invasions: what's what and the way forward. Trends Ecol Evol 28:58-66. https://doi.org/10.1016/j.tree.2012.07.013

Smaal AC, Kater BJ, Wijsman J (2009) Introduction, establishment and expansion of the Pacific oyster Crassostrea gigas in the Oosterschelde (SW Netherlands). Helgol Mar Res 63:75-83. https://doi.org/10.1007/s10152-008-0138-3

Snyder WE, Evans EW (2006) Ecological effects of invasive arthropod generalist predators. Annu Rev Ecol Evol Syst 37:95-122. https:// doi.org/10.2307/annurev.ecolsys.37.091305.30000006

Stachowicz JJ, Fried H, Osman RW et al (2002) Biodiversity, invasion resistance, and marine ecosystem function: reconciling pattern and process. Ecology 83:2575-2590. https://doi.org/10.2307/3071816

State of Victoria (2010) Invasive plants and animals policy framework. In: Department of economic development, jobs, transport and resources. http://agriculture.vic.gov.au/agriculture/pests-diseasesand-weeds/protecting-victoria-from-pest-animals-and-weeds/ invasive-plants-and-animals/invasive-plants-and-animals-policyframework. Accessed 11 Mar 2018

Stickle WB, Sabourin TD (1979) Effects of salinity on the respiration and heart rate of the common mussel, Mytilus edulis L., and the black chiton, Katherina tunicata (Wood). J Exp Mar Bio Ecol 41:257-268. https://doi.org/10.1016/0022-0981(79)90135-7

Tepolt CK, Somero GN (2014) Master of all trades: thermal acclimation and adaptation of cardiac function in a broadly distributed marine invasive species, the European green crab, Carcinus maenas. J Exp Biol 217:1129-1138. https://doi.org/10.1242/jeb.093849

Theede H (1969) Einige neue Aspekte bei der Osmoregulation von Carcinus maenas. Mar Biol 2:114-120

Thomsen MS, Wernberg T, South PM et al (2016) Non-native Seaweeds Drive Changes in Marine Coastal Communities Around the World. In: Hu Z-M, Fraser C (eds) Seaweed phylogeography - adaptation and evolution of seaweeds under environmental change. Springer, Dordrecht, pp 147-185

Thresher RE, Kuris AM (2004) Options for managing invasive marine species. Biol Invasions 6:295-300. https://doi.org/10.1023/B:BINV $.0000034598 .28718 .2 \mathrm{e}$

Tsiamis K, Zenetos A, Deriu I et al (2018) The native distribution range of the European marine non-indigenous species. https://doi. org/10.3391/ai.2018.13.2.01

Tsutsui ND, Suarez AV, Holway DA et al (2000) Reduced genetic variation and the success of an invasive species. Proc Natl Acad Sci USA 97:5948-5953. https://doi.org/10.1073/pnas.100110397

Ünal V, Bodur HG (2017) The socio-economic impacts of the silvercheeked toadfish on small-scale fishers: a comparative study from the Turkish coast. Ege J Fish Aquat Sci 34:119-127. https://doi. org/10.12714/egejfas.2017.34.2.01

van den Brink AM, Wijnhoven S, McLay CL (2012) Competition and niche segregation following the arrival of Hemigrapsus takanoi in the formerly Carcinus maenas dominated Dutch delta. J Sea Res 73:126-136. https://doi.org/10.1016/j.seares.2012.07.006

van den Brink AM, Godschalk M, Smaal AC et al (2013) Some like it hot: the effect of temperature on brood development in the invasive crab Hemigrapsus takanoi (Decapoda: Brachyura: Varunidae). J Mar Biol Assoc United Kingdom 93:189-196. https://doi. org/10.1017/S0025315412000446

Viard F, Ellien C, Dupont L (2006) Dispersal ability and invasion success of Crepidula fornicata in a single gulf: Insights from genetic markers and larval-dispersal model. Helgol Mar Res 60:144-152. https://doi.org/10.1007/s10152-006-0033-8

Vila M, Abós-Herràndiz R, Isern-Fontanet J et al (2016) Establishing the link between Ostreopsis cf. ovata blooms and human health 
impacts using ecology and epidemiology. Sci Mar 80:107-115. https://doi.org/10.3989/scimar.04395.08A

Vitousek PM, D’Antonio CM, Loope LL et al (1996) Biological invasions as global environmental change. Am Nat 84:468-478

Vranken S, Bosch S, Peña V et al (2018) A risk assessment of aquarium trade introductions of seaweed in European waters. Biol Invasions:1-17. https://doi.org/10.1007/s10530-017-1618-7

Wiedenmann J, Baumstark A, Pillen TL et al (2001) DNA fingerprints of Caulerpa taxifolia provide evidence for the introduction of an aquarium strain into the Mediterranean Sea and its close relationship to an Australian population. Mar Biol 138:229-234. https://doi. org/10.1007/s002270000456

Williams SL, Grosholz ED (2002) Preliminary reports from the Caulerpa taxifolia invasion in southern California. Mar Ecol Prog Ser 233:307-310. https://doi.org/10.3354/meps233307

Williams SL, Grosholz ED (2008) The invasive species challenge in estuarine and coastal environments: marrying management and science. Estuar Coast 31:3-20. https://doi.org/10.1007/ s12237-007-9031-6

Wilson JRU, Dormontt EE, Prentis PJ et al (2009) Something in the way you move: dispersal pathways affect invasion success. Trends Ecol Evol 24:136-144. https://doi.org/10.1016/j.tree.2008.10.007

Wolff WJ (2005) Non-indigenous marine and estuarine species in The Netherlands. Zool Meded Leiden 79:1-116

Yang J, Li Q, Kong L et al (2008) Genetic structure of the veined rapa whelk (Rapana venosa) populations along the coast of China. Biochem Genet 46:539-548. https://doi.org/10.1007/s10528-008-9168-4

Zenetos A, Apostolopoulos G, Crocetta F (2016) Aquaria kept marine fish species possibly released in the Mediterranean Sea: first confirmation of intentional release in the wild. Acta Ichthyol Piscat 46:255-262. https://doi.org/10.3750/AIP2016.46.3.10

Zeng Y, McLay CL, Yeo DCJ (2014) Capital or income breeding crabs: who are the better invaders? Crustaceana 87:1648-1656. https://doi. org/10.1163/15685403-00003385
Open Access This chapter is licensed under the terms of the Creative Commons Attribution 4.0 International License (http://creativecommons.org/licenses/by/4.0/), which permits use, sharing, adaptation, distribution and reproduction in any medium or format, as long as you give appropriate credit to the original author(s) and the source, provide a link to the Creative Commons license and indicate if changes were made.
The images or other third party material in this chapter are included in the chapter's Creative Commons license, unless indicated otherwise in a credit line to the material. If material is not included in the chapter's Creative Commons license and your intended use is not permitted by statutory regulation or exceeds the permitted use, you will need to obtain permission directly from the copyright holder. 